\title{
Influence of temperature and photoperiod on the germination of Senegalia bahiensis seeds
}

\section{Influência da temperatura e fotoperíodo na germinação de sementes de Senegalia bahiensis}

\author{
Thâmara Moura Lima ${ }^{1 *}$; Andrea Vita Reis Mendonça²; Cristiane Costa da Paixão \\ Teresa Aparecida Soares de Freitas ${ }^{2}$; Ricardo Franco Cunha Moreira ${ }^{2}$
}

\begin{abstract}
Senegalia bahiensis (Fabaceae family, Mimosoideae subfamily) is typical of an anthropic environment, and thus tolerates high levels of disturbance, which supports its use in restoration planting. However, widespread use and marketing of $S$. bahiensis seeds requires seed quality control, for which there is a dearth of protocols. The aim of the present study was to evaluate the influence of temperature and photoperiod on the germination of Senegalia bahiensis seeds from different matrix trees. Seeds were collected from fruits of 15 matrix trees in the municipality of Castro Alves, Bahia, Brazil. Two assays were performed, one for each parameter tested. The experimental design of both assays was completely randomized in a factorial design, and included three replicates of 25 seeds. The design of the first assay was 15 (matrix trees) $\times 3$ (conditions $-25^{\circ} \mathrm{C}, 30^{\circ} \mathrm{C}$ and alternating temperatures between 25 and $30^{\circ} \mathrm{C}$ ) and the design of the second assay was 14 (matrix trees) $\times 3$ (conditions -8 or 12 hours of light, or continuous light). The percentage of germination of normal seedlings, germination speed index, mean root length based on total seed number, shoot length, root length and total length were determined. The Tukey's test was used to compare mean values. The S. bahiensis matrix trees used in this study have different requirements in terms of temperature and photoperiod for seed germination. According to our findings, combining a temperature of $30^{\circ} \mathrm{C}$ and an $8 \mathrm{~h}$ period of light conveys the most suitable conditions to conduct germination tests for most matrix trees.
\end{abstract}

Key words: Forest species. Matrix trees. Propagation. White hawthorn.

\section{Resumo}

O espinheiro-branco (Senegalia bahiensis) é árvore típica de ambientes antrópicos, tolerando altos níveis de perturbação, o que a torna adequada para plantio de restauração. Contudo, seu amplo uso e comercialização dependem de haver controle de qualidade, mas não há protocolos para isto. O objetivo do presente estudo foi avaliar a influência da temperatura e fotoperíodo na germinação de diferentes matrizes de Senegalia bahiensis. As sementes foram colhidas de frutos de 15 árvores matrizes, no município de Castro Bahia. Foram instalados dois experimentos, um para cada fator abiótico testado. $\mathrm{O}$ delineamento experimental para ambos os ensaios foi inteiramente casualizado, em esquema fatorial, com três repetições de 25 sementes, sendo o primeiro experimento de 15 (matrizes) $\times 3\left(25^{\circ} \mathrm{C}, 30^{\circ} \mathrm{C}\right.$ e alternada $\left.25^{\circ}-30^{\circ} \mathrm{C}\right)$ e o segundo de 14 (matrizes) $\times 3(8 \mathrm{~h}, 12$ horas de luz e contínua). Foi determinado o percentual de germinação de plântulas normais, índice de velocidade de germinação, comprimento

\footnotetext{
${ }^{1}$ Discente de Doutorado, Universidade Estadual de Santa Cruz, UESC, Ilhéus, BA, Brasil. E-mail: thamaralima6@hotmail.com

2 Profs. Adjuntos, Universidade Federal do Recôncavo da Bahia, UFRB, Centro de Ciências Agrárias, Ambientais e Biológicas, Cruz das Almas, BA, Brasil. E-mail: andrea@ufrb.edu.br; teresa@ufrb.edu.br; ricardofcm@ufrb.edu.br

${ }^{3}$ Eng $^{\text {a }}$ Florestal, UFRB, Centro de Ciências Agrárias, Ambientais e Biológicas, Cruz das Almas, BA, Brasil. E-mail: qmimo@ hotmail.com

* Author for correspondence
} 
médio de raiz com base no número total de sementes, comprimento da parte aérea, raiz e total. Foi utilizado o teste de Tukey para comparação de médias. As matrizes de S. bahiensis, utilizadas neste estudo, diferem quanto as exigências dos fatores testados na germinação. Assim, a $30^{\circ} \mathrm{C}$ sob $8 \mathrm{~h}$ de luz é a condição mais indicada para condução de testes de germinação para a maioria das matrizes.

Palavras-chave: Espécie florestal. Espinheiro branco. Matrizes. Propagação.

\section{Introduction}

Senegalia bahiensis (Fabaceae family, Mimosoideae subfamily) is typical of an anthropic environment, and thus tolerates high levels of disturbance (SILVA et al., 2012b), which supports its use in restoration planting. In addition, $S$. bahiensis is one of the most important species for the beekeeping of Apis mellifera L. (CARVALHO; MARCHINI, 1999). This species is present in several physiognomies of the Caatinga semi-arid biome in Brazil, but also in open and degraded areas (QUEIROZ, 2009) and in the Atlantic Forest, in the coastal regions of Brazil (MORIM; BARROS, 2015).

However, widespread use and marketing of S. bahiensis seeds requires seed quality control, regulated in Brazil by Federal Law number 10.711 (BRASIL, 2003) and Federal Decree number 5.153 of July 23, 2004 (BRASIL, 2004), whose key parameters include germination potential, for which there is a dearth of protocols. The demand for seeds of native forest plants tends to increase with the need of solving environmental problems and with the increasing acceptance of multiple land-use models to generate income. However, the formalization of marketing activities and seed quality control in these species is still insufficient, especially in terms of protocols for germination tests (WIELEWICKI et al., 2006; ALVES et al., 2008).

The ideal conditions for germination tests, including environmental factors such as water availability and quality, exposure to light, oxygen levels and temperature (CARVALHO; NAKAGAWA, 2012; COSTA et al., 2013), differ between species. Temperature affects the percentage and speed of germination, influencing water absorption by the seed and the metabolic biochemical reactions that regulate this process (CARVALHO; NAKAGAWA, 2012).

The duration of the light period can influence germination depending on the required photoperiod of the species, as supported by studies from Araújo Neto et al. (2003), Brown and Antos (2012), Oliveira and Innecco (2012), Varisco and Simonetti (2012), Zhang (2012) and Silva et al. (2014a). According to TAKAKI (2001), all seeds have phytochrome, which controls the germination process. The activation of this pigment depends on the form in which it is present in the seeds, as well as on the distinct responses to irradiation. The Brazilian Rules for Seed Analysis (BRASIL, 2009) recommend different photoperiod conditions for some species to improve plant performance in germination tests and growth.

Even seeds from the same species may display distinct germinative behavior under different conditions of temperature and light, as individuals within the same species may have different genotype composition (SILVA et al., 2014b; SANTOS et al., 2009). Although research institutions have attempted to address the lack of information on germination protocols for native Brazilian tree species, such as Senegalia bahiensis, data are still scarce considering the great biodiversity of the Brazilian flora. Temperature affects the percentage and speed of germination, influencing water absorption by the seed and the metabolic biochemical reactions that regulate this process (CARVALHO; NAKAGAWA, 2012). Likewise, duration of the light period can influence germination, depending on the required photoperiod of the species (ARAÚJO NETO et al., 2003; BROWN; ANTOS, 2012; OLIVEIRA; INNECCO, 2012; SILVA et al., 2014a; VARISCO; SIMONETTI, 2012; ZHANG, 2012). According to 
Takaki (2001), all seeds have phytochrome, which controls the germination process, depending on how it is present in the seeds, as well as on the distinct responses to irradiation. Thus, the Brazilian Rules for Seed Analysis (BRASIL, 2009) recommend different photoperiod conditions for some species to improve plant performance in germination tests and growth.

Considering the above, the aim of this work was to evaluate the influence of temperature and photoperiod on the germination of seeds from different matrix trees of $S$. bahiensis, to determine the ideal conditions for seed germination.

\section{Material and Methods}

We performed two distinct assays to evaluate the effect of temperature and photoperiod in germination tests for seeds of the selected species. Seeds were obtained from fruits collected from 15 matrix trees of $S$. bahiensis, harvested in a Caatinga forest fragment (199 to $846 \mathrm{~m}$ altitude, 12 $2^{\circ} 44^{\prime} 34^{\prime \prime}$ $\mathrm{S}$ and $39^{\circ} 27^{\prime} 03^{\prime \prime} \mathrm{W}$ ). The climate of the region, according to Köppen's classification (ALVARES et al. , 2013), is humid tropical Af type, with an average monthly temperature of 24 to $26^{\circ} \mathrm{C}$ and an average annual rainfall ranging from 1000 to $1300 \mathrm{~mm}$.

The two assays had a completely randomized design, the first one with a factorial, $15 \times 3$ design, with 15 matrix trees and three temperature protocols $\left(25^{\circ} \mathrm{C}, 30^{\circ} \mathrm{C}\right.$ and alternating between 25 and $\left.30^{\circ} \mathrm{C}\right)$, and the second with a $14 \times 3$ design, with 14 matrix trees and three photoperiods ( 8 hours, 12 hours, and continuous light). Both assays were performed on three replicates of 25 seeds from each matrix tree. Seeds were placed on paper rolls for germination, moistened with distilled water in a ratio of 2.5 times the weight of the paper before hydration (BRASIL, 2009) and maintained in germinators. For the temperature assay, continuous light was used, and for the photoperiod experiment, we used a temperature of $30^{\circ} \mathrm{C}$.
During the first assay, germinated seeds were counted on the second, third, fifth and eighth days, whereas during the second experiment, counts were performed on the second and eighth days. We considered seeds to be germinated when we observed emission of the primary root. In both experiments, the last count revealed normal and abnormal seedlings, as well as hard and dead seeds. Using a graduated rule, we measured the root length (RL) and shoot length (SL) of normal seedlings eight days after the beginning of the experiment. We also measured the percentage of germination $(\mathrm{G}(\%))$, germination speed index (GSI) (MAGUIRE, 1962), and the root length based on total seed number (RL/ SN) (GUEDES et al., 2009).

To compare the performance of the matrix trees in the temperature and light period assays, we created rankings (Tables 3 and 5) based on the means values obtained for the parameters analyzed. Tables 4 and 5 depict the differences in performance observed among matrices and present a ranking based on the mean differences obtained for each variable analyzed. In this ranking, we assigned a positive sign $(+)$, at each parameter and experimental condition, to the matrix trees that received the positive $(+)$ sign were the ones with the best performance for that parameter at that experimental condition whereas those that received the negative sign (-) presented lower or similar performance at other experimental conditions.

Before the analysis of variance, data were analyzed for homoscedasticity with the Cochran test, and for normal distribution of residues with the Lilliefors test. When the requirements for analysis of variance were unmet, data were transformed by the $\arcsin (\mathrm{x})$ and $\ln (\mathrm{x})$ method. After testing significance with the F test, we applied the Tukey's mean test (SNEDECOR; COCHRAN, 1989). The analyses were performed using the $\mathrm{R}$ program version 2.17.1 (R DEVELOPMENT CORE TEAM, 2015). 


\section{Results and Discussion}

Analysis of variance revealed no interaction between temperature and matrix on percentage of germination $(\mathrm{G} \%)$, root length (RL) and root length by total seed number ratio (RL/SN) (Table 1). For these parameters, a temperature of $30^{\circ} \mathrm{C}$ showed statistical superiority, regardless of the matrix analyzed (Table 2).

Table 1. Analysis of variance for the values of G (\%), GSI, SL, RL, TL and RL/SN in Senegalia bahiensis subjected to different temperatures $\left(25^{\circ} \mathrm{C}, 30^{\circ} \mathrm{C}\right.$ and $\left.25^{\circ}-30^{\circ} \mathrm{C}\right)$ and under continuous light.

\begin{tabular}{lccccccc}
\hline \multicolumn{1}{c}{ Source of } & \multicolumn{7}{c}{ MS } \\
\cline { 2 - 7 } \multicolumn{1}{c}{ Variability } & DF & G (\%) & GSI & SL & RL & TL & RL/SN \\
\hline Matrix (M) & 14 & $0.32^{*}$ & $1.5^{*}$ & $1.12^{*}$ & $5.13^{*}$ & $10.04^{*}$ & $9.8^{*}$ \\
Temperature (T) & 2 & $0.11^{*}$ & $0.24^{*}$ & $1.5^{*}$ & $0.67^{*}$ & $3.65^{*}$ & $3.14^{*}$ \\
M $\times$ T & 28 & 0.03 & $0.04^{*}$ & $0.23^{*}$ & 0.26 & $0.80^{*}$ & 0.65 \\
Residue & 90 & 0.02 & 1.65 & 0.14 & 18.06 & 37.84 & 0.00 \\
VC $(\%)$ & - & 13.79 & 5.70 & 12.02 & 9.47 & 8.26 & 19.64 \\
\hline
\end{tabular}

*Significantly different from other values ( $\mathrm{F}$ test, $\mathrm{p}<0.05$ ). $\mathrm{DF}=$ degrees of freedom; $\mathrm{MS}=$ mean square; $\mathrm{VC} \%=$ variation coefficient. $\mathrm{G}(\%)$, percentage of germination in normal seedlings; GSI, germination speed index; SL, shoot length (cm), RL, root length (cm); TL, total length (cm); RL/SN, mean root length by seed number ratio $(\mathrm{cm})$.

Table 2. Influence of temperature in the percentage of germination $(\mathrm{G}(\%))$, root length $(\mathrm{RL})$ and root length by total seed number ratio (RL/SN) in Senegalia bahiensis.

\begin{tabular}{ccccccc}
\hline Temperature $\left({ }^{\circ} \mathrm{C}\right)$ & $\mathrm{G}(\%)$ & & RL $(\mathrm{cm})$ & \multicolumn{2}{c}{ RL/SN $(\mathrm{cm})$} \\
\hline 25 & $67.7^{*}$ & $\mathrm{~B}$ & 4.65 & $\mathrm{~B}$ & 3.2 & $\mathrm{~B}$ \\
30 & 75.2 & $\mathrm{~A}$ & 4.87 & $\mathrm{~A}$ & 3.6 & $\mathrm{~A}$ \\
$25-30$ & 67.4 & $\mathrm{~B}$ & 4.67 & $\mathrm{~B}$ & 3.2 & $\mathrm{~B}$ \\
\hline $\mathrm{VC}(\%) / \mathrm{MSD}$ & $13.79 / 0.06$ & & $9.47 / 0.19$ & & $19.64 / 0.3$ & \\
\hline
\end{tabular}

* Data transformed according to the equation $\arcsin (\sqrt{ } \% \mathrm{G} / 100)$. Mean values in columns followed by the same letters are not statistically different by the Tukey test at $5 \%$ probability. MSD $=$ minimal significant difference. $\mathrm{VC}(\%)=$ variation coefficient.

For $S$. bahiensis a constant temperature of $30^{\circ} \mathrm{C}$ provided the highest germination rate compared to either $25^{\circ} \mathrm{C}$ or alternating temperatures $(25$ $30^{\circ} \mathrm{C}$ protocol) (Table 2), regardless of the matrix analyzed (Table 1). This result contrasts with Malavasi (1988), who reported that forest species generally germinate better under alternating temperatures, and by a study conducted by Lessa et al. (2014) with Enterolobium contortisiliquum (Vell.) Morong, which showed better germination with alternating temperatures than with a constant temperature.
Root growth and RL/SN were also greatest at $30^{\circ} \mathrm{C}$ (Table 2). Forest species in tropical regions require temperatures above $10^{\circ} \mathrm{C}$ for primary root growth, and the optimal temperature for cell division is approximately $30^{\circ} \mathrm{C}$ (LARCHER, 2003), whereas the RL/SN parameter is sensitive to differences in vigor (GUEDES et al., 2009). Indeed, we observed that $30^{\circ} \mathrm{C}$ was the temperature that most contributed for seed vigor in the species analyzed (Table 2). Matrix trees 4 and 6 displayed the highest RL and $\mathrm{RL} / \mathrm{SN}$ values, and matrix 1 presented a high RL/ $\mathrm{SN}$ value (Table 3 ). 
Table 3. Ranking of success (+) and failure (-) of matrix trees in the mean test for the relative variables GSI, SL, TL, $\mathrm{G}(\%), \mathrm{RL}$ and $\mathrm{RL} / \mathrm{SN}$ in all temperatures tested, when an interaction was observed.

\begin{tabular}{|c|c|c|c|c|c|c|c|c|c|c|c|c|c|c|c|}
\hline \multirow{2}{*}{ Parameter } & \multicolumn{15}{|c|}{ Matrix tree } \\
\hline & 1 & 2 & 3 & 4 & 5 & 6 & 7 & 8 & 9 & 10 & 11 & 12 & 13 & 14 & 15 \\
\hline GSI $25^{\circ} \mathrm{C}$ & & & - & & & + & + & + & & & & & & + & \\
\hline $\mathrm{GSI} 30^{\circ} \mathrm{C}$ & + & & - & + & - & + & + & + & + & & & & & + & + \\
\hline GSI $25-30^{\circ} \mathrm{C}$ & + & + & - & + & - & + & + & + & + & - & & + & - & + & + \\
\hline $\mathrm{SL} 30^{\circ} \mathrm{C}$ & + & + & + & + & + & + & + & + & + & + & + & + & + & - & - \\
\hline $\mathrm{SL} 25-30^{\circ} \mathrm{C}$ & + & + & + & + & + & + & + & + & - & + & + & + & + & - & + \\
\hline $\mathrm{TL} 25^{\circ} \mathrm{C}$ & + & + & + & + & + & + & + & + & - & + & + & + & + & - & - \\
\hline $\operatorname{TL} 30^{\circ} \mathrm{C}$ & + & - & - & + & - & + & & - & - & - & - & - & - & - & - \\
\hline TL $25-30^{\circ} \mathrm{C}$ & + & - & + & + & - & + & + & + & - & + & + & + & + & - & - \\
\hline G (\%) & + & + & - & + & - & + & + & + & & - & + & - & - & - & + \\
\hline $\mathrm{RL}$ & & & & + & - & + & & & - & & & & & - & - \\
\hline $\mathrm{RL} / \mathrm{SN}$ & + & & - & + & - & + & & - & - & - & & - & - & - & \\
\hline Positive totals & 9 & 5 & 4 & 10 & 3 & 11 & 8 & 8 & 3 & 4 & 5 & 5 & 4 & 3 & 4 \\
\hline Negative totals & 0 & 2 & 5 & 0 & 7 & 0 & 0 & 2 & 6 & 3 & 1 & 3 & 3 & 8 & 5 \\
\hline
\end{tabular}

$\mathrm{G}(\%)$, percentage of germination in normal seedlings; GSI, germination speed index; SL, shoot length (cm), RL, root length $(\mathrm{cm})$; TL, total length $(\mathrm{cm})$; RL/SN, mean root length by seed number ratio $(\mathrm{cm})$.

Figure 1 compares GSI under the three temperature protocols for all matrix trees tested. Regarding GSI, matrix trees 1, 2, 4, 5, 8, 11, 13 and 14 were similar in terms of the temperatures tested, but matrix trees 3, 6, 7, 9 and 15, had higher GSI at $30^{\circ} \mathrm{C}$ and alternating temperatures $\left(25-30^{\circ} \mathrm{C}\right)$ (Figure 1). For matrix 10, the best temperatures for performance were $30^{\circ} \mathrm{C}$ and $25^{\circ} \mathrm{C}$, and matrix 12 presented higher GSI under $25-30^{\circ} \mathrm{C}$ and at $25^{\circ} \mathrm{C}$. Overall, for the GSI parameter (which indicates seed vigor), a temperature of $30^{\circ} \mathrm{C}$ can be recommended for all matrix trees, except matrix 12 , which presented a different behavior under different temperatures (Figure 1).

Figure 1. Germination speed index (GSI) in response to temperature in matrix trees of Senegalia banhiensis. Within each matrix, mean values followed by equal letters are not different in the Tukey test ( $\alpha=0.05$ ).

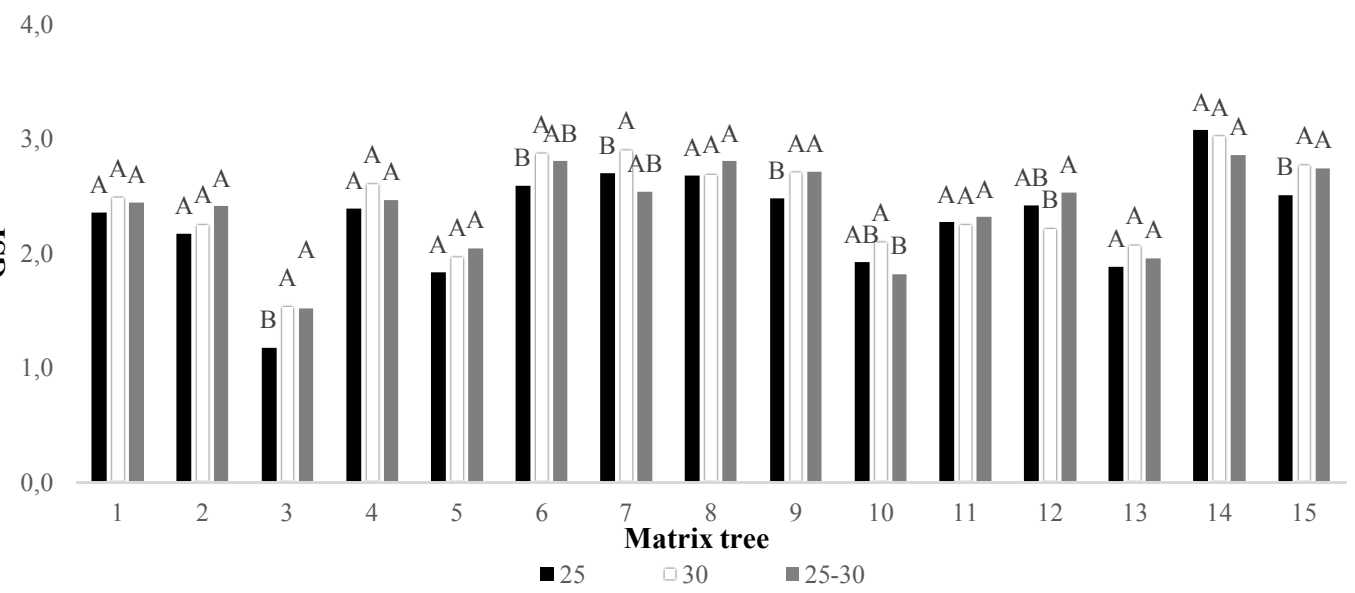


In terms of shoot length (SL), matrix trees 1,2 , $3,4,5,8,9,11,12,14$ and 15 did not respond to the temperature factor. In matrix trees 6 and 7, the shortest SL was found at $25^{\circ} \mathrm{C}$, although this was not statistically different from what was obtained under alternating temperatures. Matrix 13 had the shortest $\mathrm{SL}$ at both $25^{\circ} \mathrm{C}$ and $30^{\circ} \mathrm{C}$, and matrix 10 had the shortest $\mathrm{SL}$ at $30^{\circ} \mathrm{C}$. Overall, these results showed that alternating temperatures results in increased shoot growth (Figure 2).

As for total length, matrix trees 1, 4, 6 and 7 were not affected by the light, whereas matrix trees 2,3 , $5,8,9,10,11,12,13,14$ and 15 expressed a higher mean total length at $30^{\circ} \mathrm{C}$. We found no differences between $30^{\circ} \mathrm{C}$ and $25-30^{\circ} \mathrm{C}$ in matrix trees 1 and 7 (Figure 3).

Figure 2. Shoot length (SL) in response to temperature in matrix trees of Senegalia banhiensis. Within each matrix, mean values followed by equal letters are not different in the Tukey test $(\alpha=0.05)$.

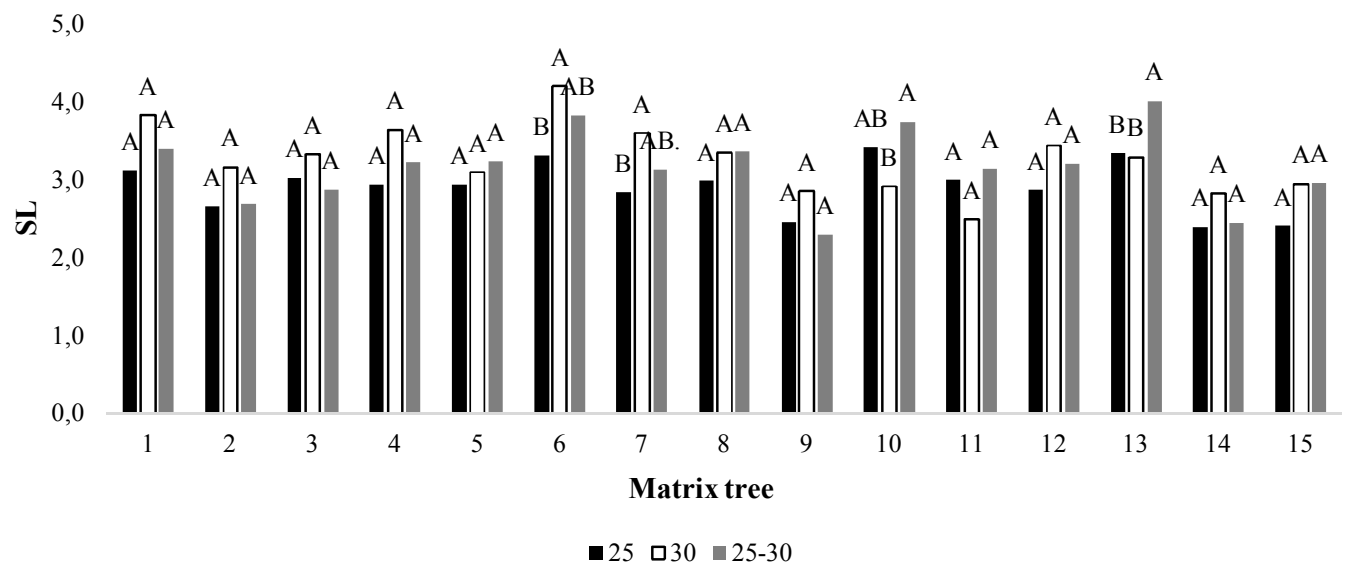

Figure 3. Total length (TL) in response to temperature in matrix trees of Senegalia banhiensis. Within each matrix, mean values followed by equal letters are not different in the Tukey test $(\alpha=0.05)$.

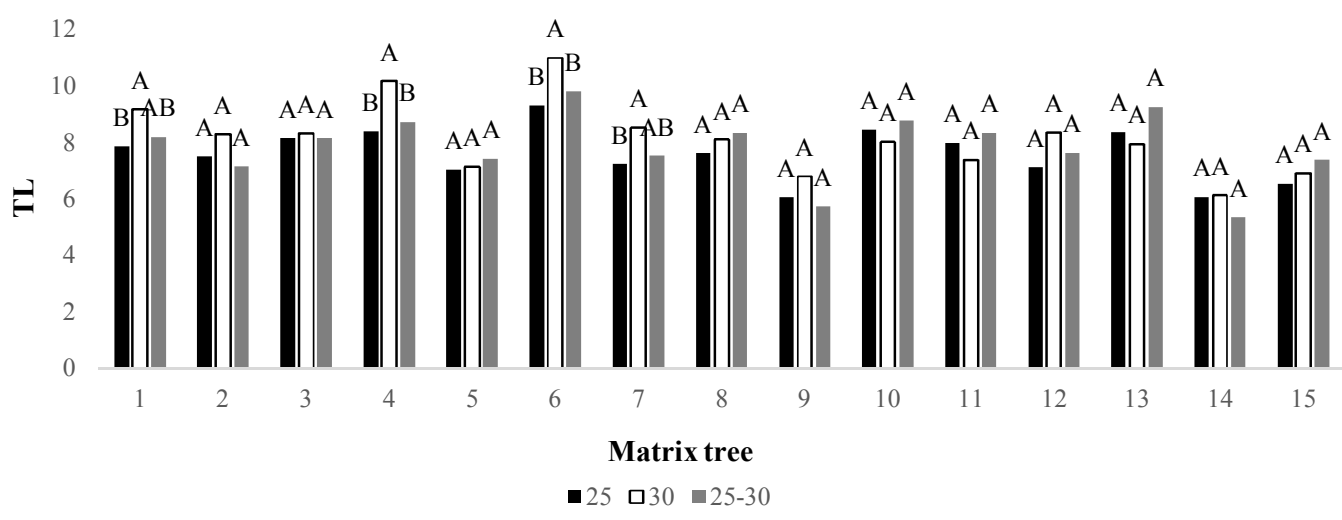


Table 3 shows the performance ranking of matrix trees for each different temperature protocol. In the germination test, the matrix with the highest performance in terms of parameters related to vigor and seed germination was matrix $6(+11)$, followed by matrix $4(+10)$ and matrix $1(+9)$. Matrix $14(-8)$ had the worst performance, followed by matrix 5 (-7) and matrix 9 (-6). These results show that matrix trees behave differently in response to temperature in terms of GSI, SL, and TL, but also have different germinative performance.

In the second assay, we observed that photoperiod influences the growth of seedling structures (SL,
RL, TL, RL/SN), but not percentage (G\%) and speed of germination (GSI) (Table 4). This may be due to the combination of the photoperiod tested and hormones, which may control seedling growth. These results are consistent with Silva et al. (2012a), who reported that photoperiod directly influences stem length, as well as leaf and root growth. Regarding shoot length (SL), matrix trees 1, 2, 6, 7, 9, 14 and 15 were indifferent to the photoperiods tested. For matrix trees 3, 4, 11 and 13, both $8 \mathrm{~h}$ and $12 \mathrm{~h}$ of light resulted in higher SL than continuous light. For matrix trees 8 and 10, the best photoperiod was $8 \mathrm{~h}$, whereas matrix 5 preferred $12 \mathrm{~h}$ of light (Table 4 and Figure 4).

Table 4. Analysis of variance for G (\%), GSI, SL, TL, G (\%), RL and RL/SN in Senegalia bahiensis seeds subjected to different photoperiods $\left(8 \mathrm{~h}, 12 \mathrm{~h}\right.$ and continuous light) at $30^{\circ} \mathrm{C}$.

\begin{tabular}{lccccccc}
\hline \multirow{2}{*}{ Source of variation } & \multicolumn{7}{c}{ MS } \\
\cline { 2 - 7 } & DF & G (\%) & GSI & SL & RL & TL & RL/SN \\
\hline Matrix (M) & 13 & $1,662.54^{*}$ & $27.01^{*}$ & $1.61^{*}$ & $5.74^{*}$ & $11.84^{*}$ & $20.57^{*}$ \\
Photoperiod (P) & 2 & 182.19 & 0.93 & $3.71^{*}$ & $6.24^{*}$ & $18.69^{*}$ & $11.58^{*}$ \\
$\mathrm{M} \times \mathrm{P}$ & 26 & 114.75 & 1.15 & $0.26^{*}$ & $0.74^{*}$ & $1.43^{*}$ & $2.12^{*}$ \\
Residue & 84 & 112.12 & 0.86 & 0.09 & 0.15 & 0.42 & 0.47 \\
VC (\%) & - & 13.40 & 7.92 & 8.68 & 7.74 & 7.37 & 16.42 \\
\hline
\end{tabular}

*Significant at the $5 \%$ level. by the $\mathrm{F}$ test $(\mathrm{p}<0.05)$. DF= degrees of freedom; $\mathrm{MS}=$ mean square; VC $\%=$ variation coefficient; $(\mathrm{G}(\%))$ percentage of germination; $(\mathrm{GSI})=$ germination speed index; $\mathrm{SL}=$ shoot length $(\mathrm{cm}) ; \mathrm{RL}=\operatorname{root}$ length $(\mathrm{cm}) ; \mathrm{TL}=$ total length $(\mathrm{cm}) ; \mathrm{RL} / \mathrm{SN}=$ Mean root length based on seed number $(\mathrm{cm})$.

Figure 4. Shoot length (SL) in response to photoperiod in matrix trees of Senegalia banhiensis. Within each matrix. mean values followed by equal letters are not different in the Tukey test $(\alpha=0.05)$.

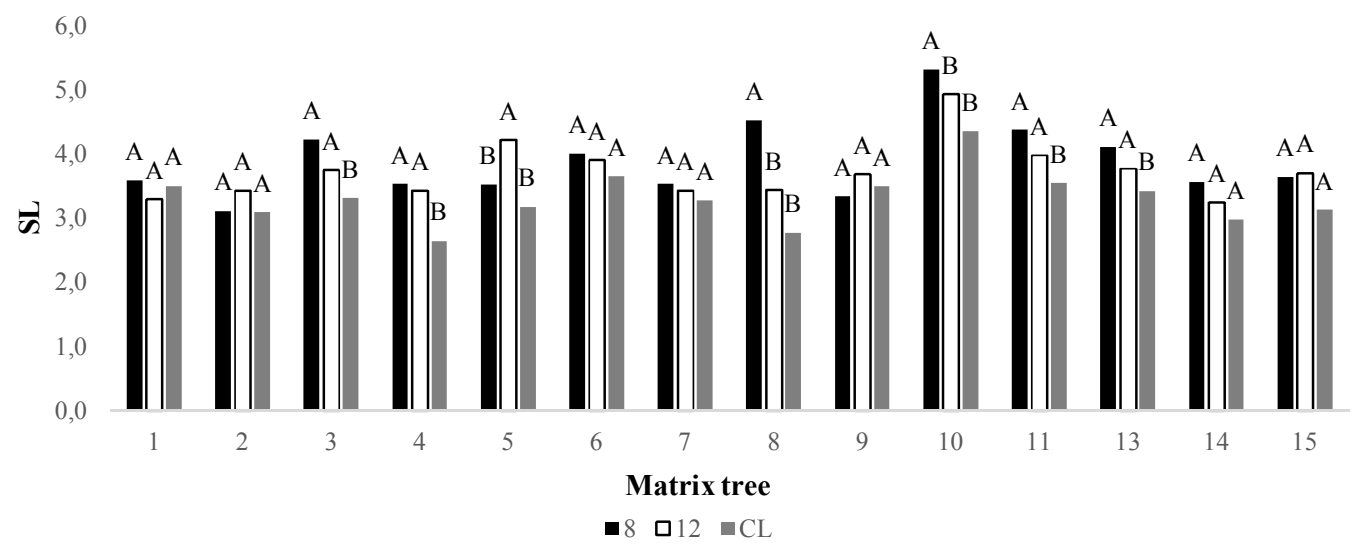


Root length in matrix trees 2, 4, 6, 7, 9, 13, 14 and 15 was not influenced by photoperiod, but in matrix trees 1, 3, 8 and 11, $8 \mathrm{~h}$ of light favored increased root length. Matrix trees 5 and 10 presented a high performance after both $8 \mathrm{~h}$ and $12 \mathrm{~h}$ of light (Table 4 and Figure 5).
Total length was not influenced by light in matrix trees 2, 6, 7, 9, 13, 14 and 15, whereas matrix trees $1,3,8$ and 11 presented higher growth after a photoperiod of $8 \mathrm{~h}$. Also, both 8 and $12 \mathrm{~h}$ of light resulted in greater total length in matrix trees 4 and 10. Matrix 5 grew more after a photoperiod of $12 \mathrm{~h}$ (Table 4 and Figure 6).

Figure 5. Root length (RL) in response to photoperiod in matrix trees of Senegalia banhiensis. Within each matrix. mean values followed by equal letters are not different in the Tukey test $(\alpha=0.05)$

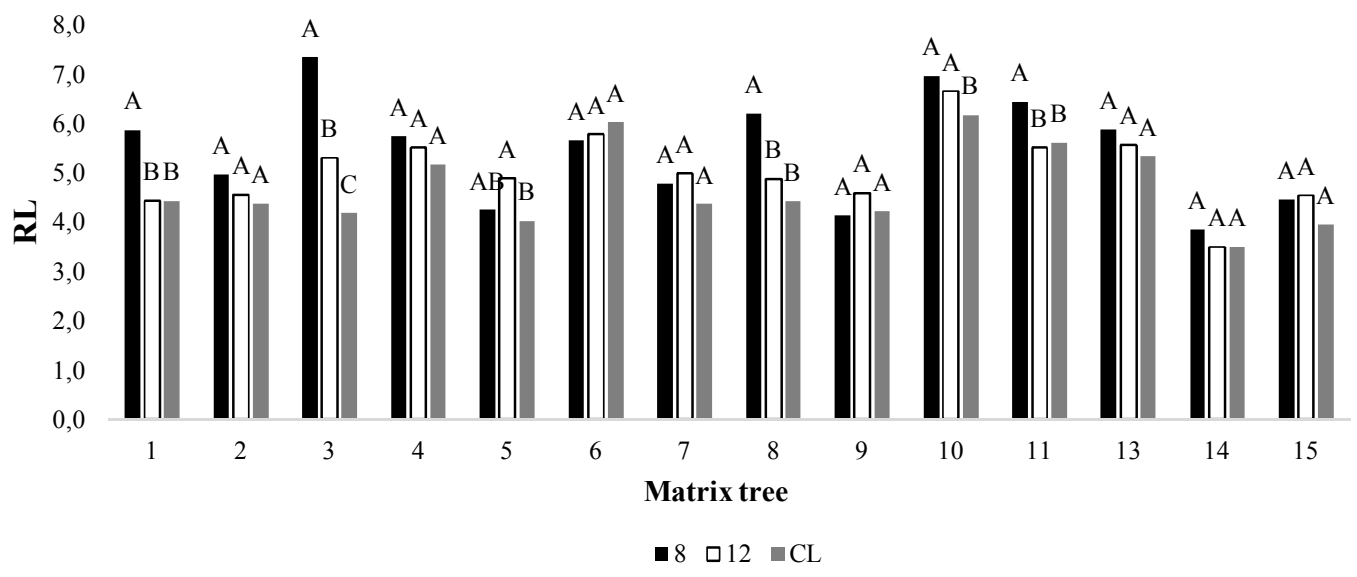

Figure 6. Total length (TL) in response to photoperiod in matrix trees of Senegalia banhiensis. Within each matrix. mean values followed by equal letters are not different in the Tukey test $(\alpha=0.05)$.

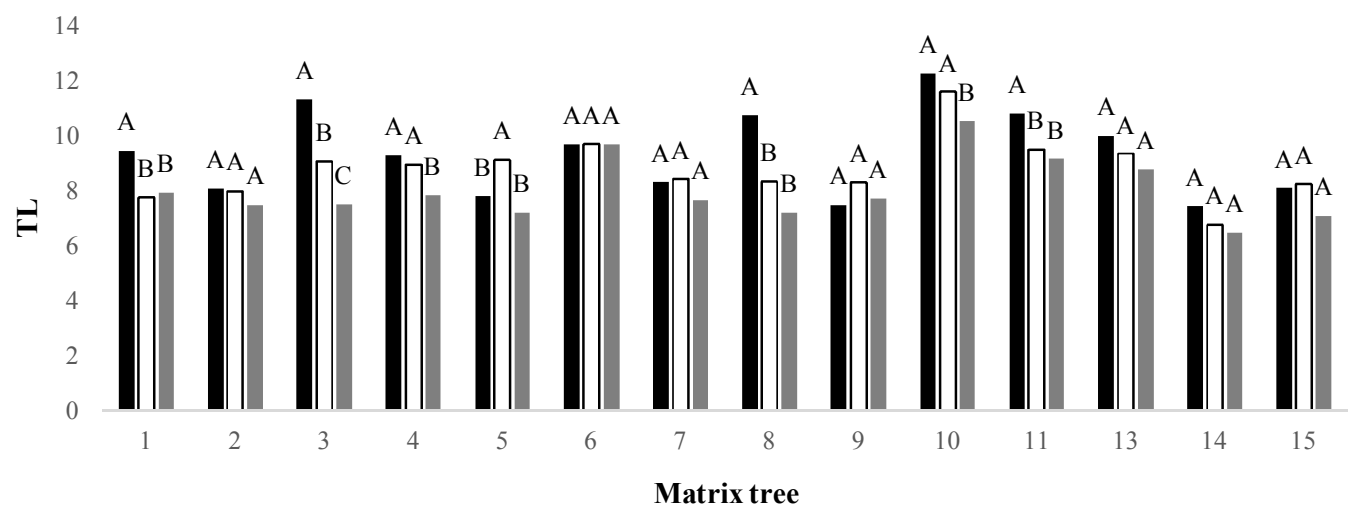

ロ 812 ㄴC

Root length based on the total seed number (RL/ $\mathrm{SN})$ was not influenced by light in matrix trees 2 , $4,5,6,7,9,11,13,14$ and 15. Matrix trees 1, 3,
8 and 10 had higher RL/SN after a photoperiod of $8 \mathrm{~h}$, whereas matrix trees 3 and 8 presented similar values after $8 \mathrm{~h}$ and $12 \mathrm{~h}$ of light (Figure 7 ). 
Figure 7. Mean root length based on seed number (RL/SN) in response to photoperiod in matrix trees of Senegalia banhiensis. Within each matrix. mean values followed by equal letters are not different in the Tukey test $(\alpha=0.05)$.

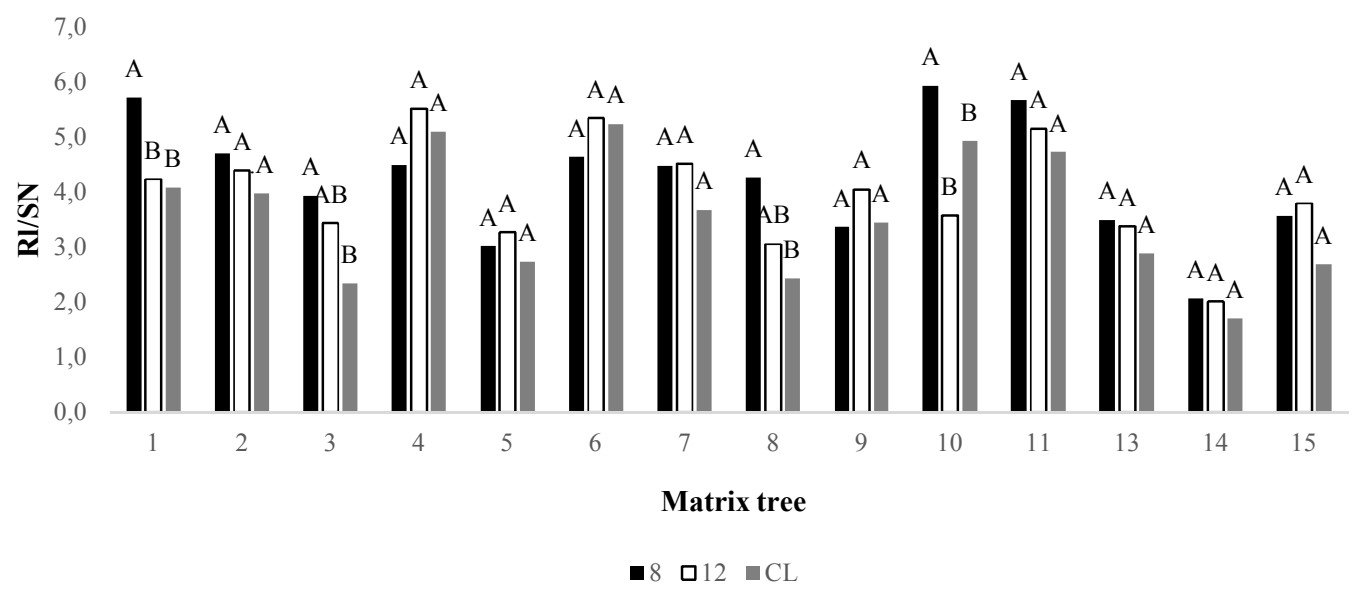

As $S$. bahiensis can be found in the Caatinga (QUEIROZ, 2009) and the matrix trees used in this work were collected from a representative fragment of this biome, it was expected that photoperiod preferences were in accordance with the climatic conditions of this location. According to Nogueira et al. (2014), in the Caatinga biome species take advantage of the short rainy season for seed germination, similar to what occurs in other dry plant formations. Dry climate species guarantee their establishment during the rainy season when irradiation is reduced (RINCÓN; HUANTE, 1993) and the photoperiod is shorter. Therefore, the preference of $S$. bahiensis for a photoperiod of $8 \mathrm{~h}$ for germination is consistent with the climatic conditions of the natural habitat of this species.

Our results also show that matrix trees of $S$. bahiensis respond differently to light exposure. While the seeds from six matrix trees $(2,6,7,9$, 14 and 15) were not responsive to photoperiods tested in all the parameters analyzed, others were influenced by light exposure. According to Marcos Filho (2005), the light effect generates a variability of responses between different species and even within the same species or individual.

To compare the performance of the matrix trees in the photoperiod assay, we created a ranking (Table 5) based on the mean values obtained for the parameters analyzed. The matrix trees with the best performance were 10 and 11 , followed by matrix 6. Matrix 14 had the worst performance, followed by matrix trees 5 and 15 . In the temperature assay, matrix 6 was also among the best and matrix trees 14 and 5 were among those of inferior performance. It should be noted that the photoperiod assay was performed approximately one month after the temperature assay, and the difference between the experiments can be related to seed storage.

Differences between seed quality and germination among matrix trees of the same species were also reported in other studies. Lima et al. (2014) found differences in the physiological quality of the seeds among matrix trees of Poincianella pyramidalis (Tul.) L. P. Queiroz obtained from the same collection area. Silva et al. (2014b) found great variability in the biometric characteristics of fruits, seeds, and germination among matrix trees of Sideroxylon obtusifolium (Roem. \& Schult.) T.D. Penn.

According to Silva et al. (2014b), variation in the germination process within the same species may be caused by factors such as high genetic variability due to non-domestication and alogamy. Other factors, such as variation in environmental conditions (edaphic conditions, position relative to radiation, among others) and border effect (MENDONÇA et al., 2014), may also influence germination. 
Table 5. Ranking of success (+) and failure (-) of matrix trees in the mean test for the relative variables GSI. SL. TL. $\mathrm{G}(\%) . \mathrm{RL}$ and RL/SN in all temperatures tested. when an interaction was observed.

\begin{tabular}{|c|c|c|c|c|c|c|c|c|c|c|c|c|c|c|}
\hline \multirow[b]{2}{*}{ Parameters } & \multicolumn{14}{|c|}{ Matrix trees } \\
\hline & 1 & 2 & 3 & 4 & 5 & 6 & 7 & 8 & 9 & 10 & 11 & 13 & 14 & 15 \\
\hline G(\%) & + & + & - & + & - & + & + & + & + & & + & - & - & \\
\hline GSI & + & + & - & & - & + & + & + & + & - & & - & & + \\
\hline SL (8h) & - & - & & - & - & - & - & + & - & + & + & & - & - \\
\hline SL (12h) & - & - & - & - & + & - & - & - & - & + & + & - & - & - \\
\hline SL (LC) & + & - & - & - & - & + & - & - & + & + & + & + & - & - \\
\hline $\mathrm{RL}(8 \mathrm{~h})$ & & - & + & & - & & - & + & - & + & + & & - & - \\
\hline $\mathrm{RL}(12 \mathrm{~h})$ & - & - & & & & + & & & - & + & & + & - & - \\
\hline RL (LC) & - & - & - & + & - & + & - & - & - & + & + & + & - & - \\
\hline TL (8h) & & - & + & - & - & & - & + & - & + & + & & - & - \\
\hline TL (12h) & - & - & & & & & - & - & - & + & & & - & - \\
\hline TL (LC) & - & - & - & - & - & + & - & - & - & + & + & + & - & - \\
\hline RL/SN (8h) & + & + & + & + & - & + & + & + & - & + & + & - & - & - \\
\hline RL/SN (12h) & + & + & - & + & - & + & + & - & + & - & + & - & - & + \\
\hline RL/SN (LC) & + & + & - & + & - & + & + & - & + & + & + & + & - & - \\
\hline Positive totals & 6 & 5 & 3 & 5 & 1 & 9 & 5 & 6 & 5 & 11 & 11 & 5 & 0 & 2 \\
\hline Negative totals & 6 & 9 & 8 & 5 & 11 & 2 & 8 & 7 & 9 & 2 & 0 & 5 & 13 & 11 \\
\hline
\end{tabular}

$\mathrm{G}(\%)$, percentage of germination in normal seedlings; GSI, germination speed index; SL, shoot length (cm), RL, root length (cm); $\mathrm{TL}$, total length (cm); RL/SN, mean root length by seed number ratio (cm); $8,8 \mathrm{~h}$ of light exposure;12, $12 \mathrm{~h}$ of light exposure; CL, continuous light exposure.

Thus, to compose homogeneous lots that meet the requirements of the Brazilian Instructions for Seed Analysis in Forest Species (BRASIL, 2013), it is necessary to consider the differences between matrix trees, and form appropriate lots by grouping seeds from matrix trees with a similar response in germination and germinative performance.

Considering the results obtained in our work, we suggest the creation of three performance groups regarding seed response to temperature and light: GROUP 1 (matrix trees of high performance and germination after $8 \mathrm{~h}$ of light at a temperature of $30^{\circ} \mathrm{C}$ ) - matrix trees $1,4,6,10$ and 11 ; GROUP 2 (matrix trees of intermediate performance and germination after $8 \mathrm{~h}$ of light at a temperature of $30^{\circ} \mathrm{C}$ ) - matrix trees 2, 3, 7, 8 and 13; and GROUP 3 (matrix trees of low performance and germination after a photoperiod of $12 \mathrm{~h}$ at a temperature of $30^{\circ} \mathrm{C}$ ) - matrix trees 5, 9, 14 and 15 .

\section{Conclusion}

The $S$. bahiensis matrix trees used in this study have different requirements of temperature and photoperiod to germinate. We observed that a temperature of $30^{\circ} \mathrm{C}$ and a photoperiod of $8 \mathrm{~h}$ represent optimal conditions to conduct germination tests for most of these matrix trees.

\section{References}

ALVARES, C. L.; STAPE, J. L.; SENTELHAS, P. C.; GONÇALVES, J. L. M.; SPAROVEK, G. Köppen's climate classification map for Brasil. Meteorologische Zeitschrift, Stuttgart, v. 22, n. 6, p. 711-728, 2013.

ALVES, E. U.; NASCIMENTO, C. D. L.; BRUNO, R. L. A.; ALVES, A. U.; BRAGA JÚNIOR, J. M.; CARDOSO, E. A.; GALINDO, E. A.; SILVA, K. B. Germinação e vigor de sementes de Bauhinia divaricata L. Ciência Rural, Santa Maria, v. 38, n. 4, p. 960-966, 2008.

ARAÚJO NETO, J. C.; AGUIAR, I. B.; FERREIRA, V. M. Efeito da temperatura e da luz na germinação de sementes de Acacia polyphylla DC. Revista Brasileira de Botânica, São Paulo, v. 26, n. 2, p. 249-256, 2003. 
BRASIL. Decreto $\mathrm{n}^{\circ}$ 5.153, de 23 de julho de 2004. Regulamentação da Lei $\mathrm{n}^{\circ} 10.711$, de 5 de agosto de 2003, que dispõe sobre o Sistema Nacional de Sementes e Mudas - SNSM, e dá outras providências. Diário Oficial [da] República Federativa do Brasil, Poder Executivo, Brasília, 23 jul. 2004. Seção I, p. 90-93.

Lei n. 10.711, de 5 de agosto de 2003. Dispõe sobre o Sistema Nacional de Sementes e Mudas- SNSM, e dá outras providências. Diário Oficial [da] República Federativa do Brasil. Poder Executivo, Brasília, 5 ago. 2003. Seção III, p. 87-89.

BRASIL, Ministério da Agricultura, Pecuária e Abastecimento. Instruções para análise de sementes de espécies florestais, de 17 de janeiro de 2013. Brasília: MAPA, 2013. 98 p.

Ministério da Agricultura, Pecuária e Abastecimento. Regras para análise de sementes. Secretaria de Defesa Agropecuária. Brasília: MAPA/ ACS5, 2009. 395 p.

BROWN, K. R.; ANTOS, J. A. Seed banks, germination and early survival of bitter cherry (Prunus emarginata) in coastal British Columbia. Forest Ecology and Management, Vantaa, v. 282, n.8, p. 92-104, 2012.

CARVAlHO, C. A. L.; MARCHINI, L. C. Plantas visitadas por Apis mellifera L. no vale do rio Paraguaçu, Município de Castro Alves, Bahia. Revista Brasileira de Botânica, São Paulo, v. 22, n. 2, p. 333-338, out. 1999.

CARVALHO, N. M.; NAKAGAWA, J. Sementes: ciência, tecnologia e produção. 5. ed. Jaboticabal: FUNEP, 2012. $155 \mathrm{p}$.

COSTA, E. S.; SANTOS NETO, A. L.; COSTA, R. N.; SILVA, J. V.; SOUZA, A. A.; SANTOS, V. R. Dormência de sementes e efeito da temperatura na germinação de sementes de mororó. Revista Ciências Agrárias, Recife, v. 56, n. 1, p. 19-24, 2013.

GUEDES, R. S.; ALVES, E. U.; GONÇALVES, E. P.; BRUNO, R. L. A.; BRAGA-JÚNIOR, J. M.; MEDEIROS, M. S. Germinação de sementes de Cereus jamacaru DC. em diferentes substratos e temperaturas. Acta Scientiarum. Biological Sciences. Maringá, v. 32, n. 3, p. 159-164, 2009.

LARCHER, W. Physiological plant ecology: ecophysiology and stress physiology of functional groups. Berlin: Springer, 2003. 533 p.

LESSA, B. F. T.; ALMEIDA, J. P. N.; PINHEIRO, C. L.; NOGUEIRA, F. C. B.; MEDEIROS FILHO, S. Germinação e crescimento de plântulas de Enterolobium contortisiliquum (vell.) morong em função da localização da semente no fruto e regimes de temperatura. Bioscience Journal, Uberlândia, v. 30, n. 5, p. 1474-1483, 2014.
LIMA, C. R.; BRUNO, L. A.; SILVA, K. R. G.; PACHECO, M. V.; ALVES, E. U. Qualidade fisiológica de sementes de diferentes árvores matrizes de Poincianella pyramidalis (Tul.) L. P. Queiroz. Revista Ciência Agronômica, Fortaleza, v. 45, n. 2, p. 370-378, 2014.

MAGUIRE, J. D. Speed of germination-aid in selection and evaluation for seedlig emergence and vigor. Crop Science, Madison, v. 2, n. 1, p. 176-177, 1962.

MALAVASI, M. M. Germinação de sementes. In: PIÑARODRIGUES, F. C. M. (Ed.). Manual de análise de sementes florestais. Campinas: Fundação Cargill, 1988. p. 25-40.

MARCOS FILHO, J. Fisiologia de sementes de plantas cultivadas. Piracicaba: FEALQ, 2005. 495 p.

MENDONÇA, A. V. R.; PASSOS, L. G.; VICTORJUNIOR, V. V.; FREITAS, T. A. S.; SOUZA, J. S. Produção e armazenamento de sementes de Poincianella pyramidalis (Tul.) L. P. Queiroz, em resposta a diferentes ambientes de coleta. Agrária, Recife, v. 9, n. 3, p. 413419, 2014.

MORIM, M. P.; BARROS, M. J. F. Senegalia. In: ZAPPI, D. C. Lista de espécies da flora do Brasil. Rio de Janeiro: BRASIL, 2015. p. 52-76. Disponível em: <http:// floradobrasil.jbrj.gov.br/jabot/floradobrasil/FB1009 98>. Acesso em: 20 ago. 2015.

NOGUEIRA; F. C. B.; GALLÃO, M. I.; BEZERRA, A. M. E.; MEDEIROS FILHO, S. Efeito da temperatura e luz na germinação de sementes de Dalbergia cearensis Ducke. Ciência Florestal, Santa Maria, v. 24, n. 4, p. 997 1007, 2014.

OLIVEIRA, M. A. S.; INNECCO, R. Germinação de sementes de jambu (Acmella oleracea - Asteraceae) sob influência de fotoperíodo e temperatura. Revista Eletrônica de Biologia, Sorocaba, v. 5, n. 3, p. 105-118, 2012.

QUEIROZ, L. P. Leguminosas da Caatinga. Feira de Santana: Universidade Estadual de Feira de Santana, 2009. 467 p.

R DEVELOPMENT CORE TEAM - R: a language and environment for statistical computing. R Foundation for Statistical Computing, Vienna: ISAQ, 2015. Available at: $<$ http://www.R-project.org >. Accessed at: 10 ago. 2015.

RINCÓN, E.; HUANTE, P. Growth responses of tropical deciduous tree seedlings to contrasting light conditions. Trees, Oxford, v. 7, n. 4, p. 202-207, 1993.

SANTOS, F. S.; PAULA, R. C.; SABONARO, D. Z.; VALADARES, J. Biometria e qualidade fisiológica de sementes de diferentes matrizes de Tabebuia chrysotricha 
(Mart. Ex A. DC.) Stand I. Scientia Forestalis, Piracicaba, v. 37, n. 82, p. 163-173, 2009.

SILVA, K. B.; ALVES, E. U.; OLIVEIRA, A. N. P.; RODRIGUES, P. A. F.; SOUZA, N. A.; AGUIAR, V.A. Variabilidade da germinação e caracteres de frutos e sementes entre matrizes de Sideroxylon obtusifolium (Roem. \& Schult.) T.D. Penn. Revista Eletrônica de Biologia, Sorocaba, v. 7, n. 3, p. 281-300, 2014b.

SILVA, K. B.; ALVES, E. U.; OLIVEIRA, A. N. P.; SOUSA, N. A.; AGUIAR, V. A. Influência da luz e temperatura na germinação de sementes de quixaba. Revista AGROTEC, Porto, v. 35, n. 1, p. 13-22, 2014a.

SILVA, N. A.; COSTA, N. M.; CARVALHO, R.; SAONCELLA, A. L.; SOUZA-LEAL, T.; PEDROSODE-MORAES, C. Anatomia radicial de Oncidium flexuosum Sims. e Oncidium Sharry Baby (Orchidaceae). Natureza on line, Santa Teresa, v. 10, n. 4, p. 183-185, 2012a.

SILVA, S. O.; FERREIRA, R. L. C.; SILVA, J. A. A.; LIRA, M. A.; ALVES JUNIOR, F. T.; CANO, M. O. O.; TORRES, E. L. Regeneração natural em um remanescente de caatinga com diferentes históricos de uso no agreste pernambucano. Revista Árvore, Viçosa, MG, v. 36, n. 3, p. 441-450, 2012 b.
SNEDECOR, G. W.; COCHRAN, W. G. Statistical methods. $8^{\text {th }}$ ed. Ames: Iowa State University Press, 1989. $503 \mathrm{p}$.

TAKAKI, M. New proposal of classification of seed based on forms of phytochrome insted of photoblastism. Revista Brasileira de Fisiologia Vegetal, Londrina, v. 13, n. 1, p. 103-107, 2001.

VARISCO, M. R.; SIMONETTI, A. P. M. M. Germinação de sementes de crambe sob influência de diferentes substratos e fotoperíodos. Acta Iguazu, Cascavel, v. 1, n. 2, p. 36-46, 2012.

WIELEWICKI, A. P.; LEONHARDT, C.; SCHLINDWEIN, G.; MEDEIROS, A. C. de S. Proposta de padrões de germinação e teor de água para sementes de algumas espécies florestais presentes na região sul do Brasil. Revista Brasileira de Sementes, Londrina, v. 28, n. 3, p. 191-197, 2006.

ZHANG, H. Seed germination and early seedling growth of Cynanchum bungei decne (Asclepiadaceae) in response to photoperiod, temperature, and seed size. Hort Science, Alexandria, v. 47, n. 9, p. 1338-1341, 2012. 